\title{
Immunohistochemical investigation of secretory component and immunoglobulin $A$ in the genital tract of the female rat
}

\author{
M. B. Parr and E. L. Parr \\ Southern Illinois University, School of Medicine, Department of Anatomy, Carbondale, IL 62901, \\ U.S.A.
}

\begin{abstract}
Summary. There was intense labelling of secretory component (sc) in the glandular and luminal epithelia of the uterine horns at pro-oestrus, oestrus and Day 1 of pregnancy, but at other stages labelling was weak or undetectable. There was also intense labelling of $s c$ in the superficial layer of cells in the stratified epithelia of the cervix and vagina at pro-oestrus and Days 4-7 of pregnancy, but not at other stages. Plasma cells containing immunoglobulin $\mathrm{A}(\mathrm{IgA})$ were not observed in any region of the genital tract at any of the times studied. The presence of sc coupled with an absence of IgA-containing plasma cells suggest that $\operatorname{IgA}$ in genital tract secretions of the female rat may be derived mainly from serum.
\end{abstract}

Keywords: secretory component; female genital tract; immunoglobulin A; mucosal immunity; rat

\section{Introduction}

A local secretory immune system has been demonstrated in the female genital tract of many species (mouse: Bernard et al., 1981; Canning \& Billington, 1983; Parr, M. B. \& Parr, E. L., 1985; mare: Kenney \& Khaleel, 1975; sow: Hussein et al., 1983; cow: Curtain et al., 1971; human: Waldman et al., 1971; Ogra \& Ogra, 1973; Rebello et al., 1975). Accumulated evidence suggests that plasma cells located in the endometrium synthesize dimeric immunoglobulin A (IgA) which is transported across the epithelium by a receptor-mediated mechanism, the receptor being secretory component (sc). Secretory $\operatorname{IgA}(\mathrm{s} \operatorname{IgA})$ is then released into the lumen where it may protect the genital tract against infection (Solari \& Kraehenbuhl, 1985).

There is also evidence that a secretory immune system is present in the genital tract of the female rat, particularly the uterine horns. Pro-oestrous uterine fluid contains IgA and IgG, and the ratio of IgA to IgG is higher in these secretions than in serum (Wira \& Sandoe, 1977). Free sc and sIgA are also present in pro-oestrous uterine fluid, suggesting that sc mediates the movement of IgA from the tissue into the uterine lumen (Sullivan \& Wira, 1981). Using immunofluorescent labelling, Wira et al. (1980) reported the presence of many IgA plasma cells in the endometrium and myometrium during the oestrous cycle, and oestradiol treatment stimulated the appearance of IgA-positive cells in the uteri of ovariectomized rats (Wira et al., 1983). On the other hand, in a preliminary report, Mitchell (1986) concluded that IgA plasma cells were not present in uterine tissue from cyclic rats, but IgA was detected in the luminal and glandular epithelia, predominantly at pro-oestrus and oestrus.

Little is known about secretory immunity in the oviduct and cervico-vaginal regions of the rat. IgA and sc have been detected in cervico-vaginal secretions of rats with ligatures at the uterocervical junctions, but oestradiol treatment caused a decrease in the levels of sc and IgA (Wira \& Sullivan, 1985). 
In the present study we have further characterized the secretory immune system of the female rat by investigating sc and IgA plasma cells in the genital tract during the oestrous cycle and early pregnancy.

\section{Materials and Methods}

Virgin female Sprague-Dawley rats (Harlan, Sprague-Dawley, Inc., Indianapolis, IN, U.S.A.) 60-100 days old and

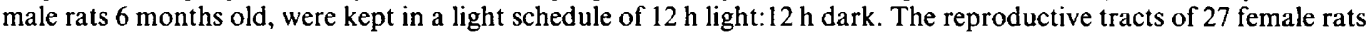
were studied at the following stages: pro-oestrus, oestrus, dioestrus, and Days 1, 4, 5, 6 and 7 of pregnancy (Table 1). The stages of the cycle, initially selected on the basis of vaginal smears, were confirmed by microscopic examination of vaginal histology (Long \& Evans, 1922). The day on which spermatozoa were found in the vagina was designated Day 1 of pregnancy. All female rats were killed and the duodenum and entire reproductive tract were removed and fixed by immersion for $6 \mathrm{~h}$ at $4^{\circ} \mathrm{C}$ in $4 \%$ paraformaldehyde in $0.05 \mathrm{M}$-phosphate buffer, or in a mixture with a final composition of $2 \%$ acetic acid and $10 \%$ formalin in $0.9 \%(\mathrm{w} / \mathrm{v})$ sodium chloride. The fixed tissues were washed overnight in $0.1 \mathrm{M}-$ phosphate buffer $\left(4^{\circ} \mathrm{C}\right)$ and embedded in polyethylene glycol (PEG) according to the method of Mazurkiewicz \& Nakane (1972). The PEG-embedded tissues were sectioned $(4 \mu \mathrm{m})$ and floated on $5 \%$ glycerol for a minimum of $1 \mathrm{~h}$ to remove the PEG, and mounted on polylysine-coated slides (Wolosewick \& De Mey, 1982). Pieces of duodenum and uterine horns from 3 non-pregnant rats were embedded in O.C.T. compound (Tissue-Tek: Miles Scientific, Naperville, IL, U.S.A.) and frozen in isopentane cooled with liquid nitrogen. Cryostat sections $(5 \mu \mathrm{m})$ were fixed in $100 \%$ methanol (room temperature) for $10 \mathrm{~min}$ and then dried.

Table 1. Immunohistochemical localization of secretory component in the genital tract of cyclic and pregnant female rats

\begin{tabular}{|c|c|c|c|c|c|}
\hline \multirow[b]{2}{*}{ Stage } & \multirow[b]{2}{*}{$\begin{array}{l}\text { No. of } \\
\text { rats }\end{array}$} & \multicolumn{2}{|c|}{ Uterine horn } & \multirow[b]{2}{*}{$\begin{array}{l}\text { Cervical } \\
\text { epithelium }\end{array}$} & \multirow[b]{2}{*}{$\begin{array}{l}\text { Vaginal } \\
\text { epithelium }\end{array}$} \\
\hline & & $\begin{array}{l}\text { Luminal } \\
\text { epithelium }\end{array}$ & $\begin{array}{l}\text { Glandular } \\
\text { epithelium }\end{array}$ & & \\
\hline Pro-oestrus & 3 & $1-2$ & 2 & $0-1 \dagger$ & 2 \\
\hline Oestrus & 3 & 3 & 3 & 0 & 0 \\
\hline Metoestrus & 2 & 1 & 1 & 0 & 0 \\
\hline Dioestrus & 2 & $1^{*}$ & $1^{*}$ & 0 & 0 \\
\hline \multicolumn{6}{|l|}{ Pregnant } \\
\hline Day I & 5 & $2-3$ & $2-3$ & 0 & 0 \\
\hline Day 4 & 3 & 0 & $0-1^{*}$ & $0-1$ & 2 \\
\hline Day 5 & 3 & 0 & $1-2$ & 1 & 2 \\
\hline Day 6 & 3 & $0-1^{*}$ & $0-1 *$ & $-\ddagger$ & $-\ddagger$ \\
\hline Day 7 & 3 & $0-1^{*}$ & $0-1 *$ & - \pm & $-_{+}^{+}$ \\
\hline
\end{tabular}

Values are for brightness of fluorescent labelling, with 0 being none and 3 the brightest.

*Label was present only in the apical part of the cell.

† Label was present only in the superficial cells of the cervical and vaginal stratified epithelia.

$\$$ Not available.

In two additional rats the cervix was transected between two ligatures, thus separating the vagina from the rest of the genital tract. The rats were allowed to recover for $3-4$ weeks, after which they were mated and killed on Day 4 of pregnancy. It was established that the uterine horns were still separated from the vaginae, and then the vaginae were processed for immunohistochemistry as described above.

To demonstrate IgA or sc, histological sections were incubated in the following reagents at room temperature with intermediate washings in PBS: $2 \%$ normal rabbit serum for $30 \mathrm{~min}$; 1/1000 dilution of goat anti-rat myeloma IgA ( $\alpha$-chain specific, Miles Scientific) or 1/100 dilution of rabbit anti-rat sc (prepared as described by Fisher et al., 1979, and donated by Dr Brian Underdown) for $1 \mathrm{~h} ; 1 / 50$ dilution of FITC-rabbit anti-goat IgG or FITC-goat anti-rabbit IgG (Zymed Laboratories, Inc., San Francisco, CA, U.S.A.) for I h. Specificities of the primary antisera were tested by substituting normal sera (goat or rabbit) for the primary antisera and by combining an excess of purified sIgA or sc with the appropriate antiserum before labelling (sc and $\operatorname{sIgA}$ were donated by Dr Brian J. Underdown). Positive controls were obtained by labelling plasma cells (IgA) and epithelial cells (sc) in sections of duodenum. Histological sections were mounted with polyvinyl alcohol and examined using an Olympus microscope equipped with epifluorescence. For each animal, 5-10 sections from each region were examined for IgA or sc immunolabelling. 

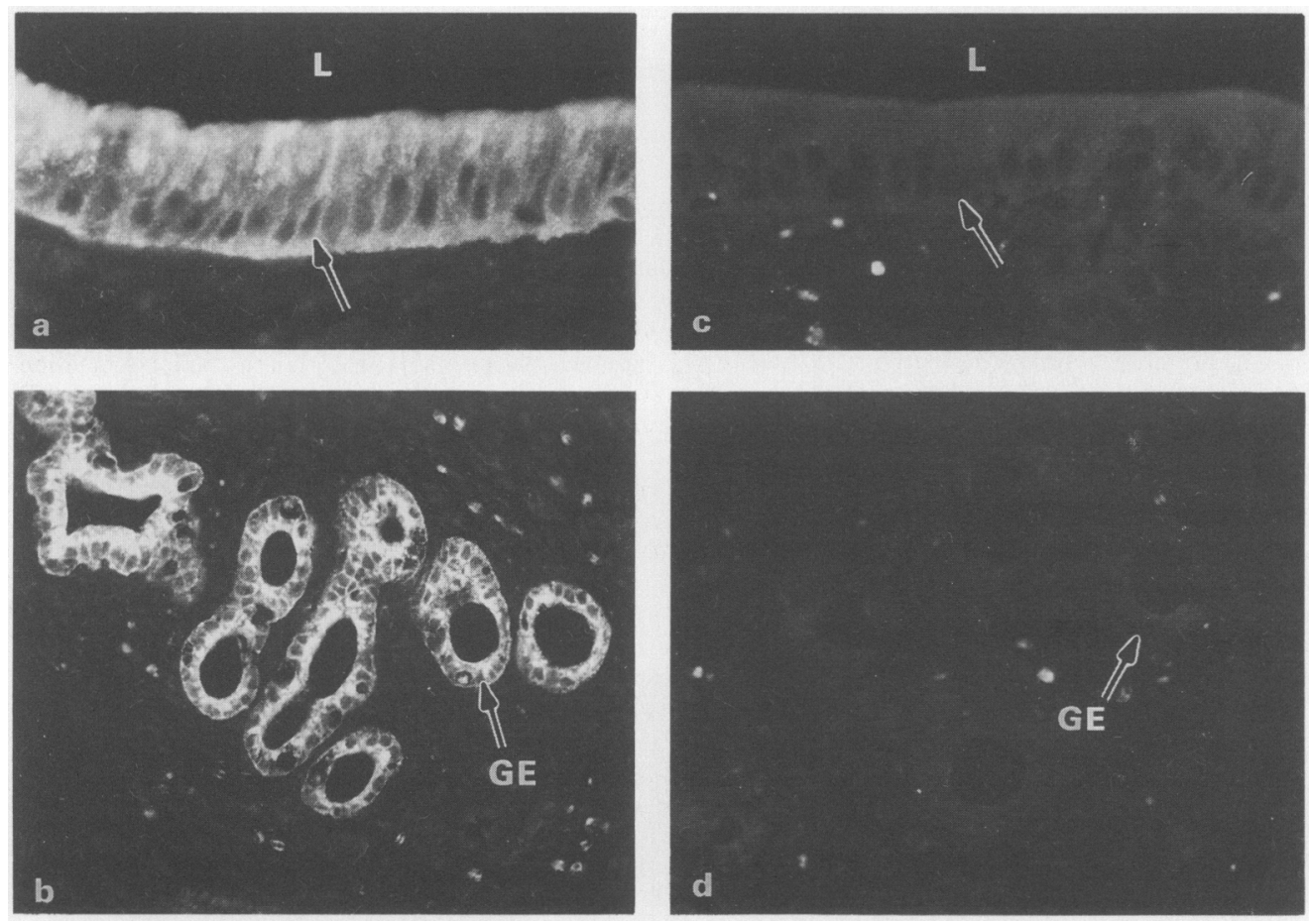

Fig. 1. The immunohistochemical labelling of sc in luminal (a) and glandular (b) epithelia in rat uterine horns at oestrus. Control sections (c, d) from regions similar to those in (a) and (b) show that the labelling of sc was blocked by the addition of purified rat sc to the anti-sc serum before labelling. Eosinophils and neutrophils in the uterine stroma show non-specific endogenous fluorescence in all micrographs. L, lumen; arrow, luminal epithelium; GE, glandular epithelium. a, $\times 310 ; \mathrm{b}, \times 180 ; \mathrm{c}, \times 310 ; \mathrm{d}, \times 190$.

\section{Results}

In the duodenum, IgA was detected in numerous plasma cells in the lamina propria of the villi, in fewer plasma cells around the glands and in glandular epithelia. The labelling was similar in tissues fixed in $4 \%$ paraformaldehyde, $2 \%$ acetic acid-10\% formalin in saline, or in frozen sections fixed in $100 \%$ methanol. Secretory component was located in the apical part of the glandular epithelial cells, along the plasma membranes of these cells, and occasionally in glandular lumina. There was no labelling of sc or IgA when non-immune sera were substituted for specific immune sera or when primary antisera were combined with an excess of purified antigens.

The localization of sc in the uterine horn, cervix, and vagina of cycling and pregnant rats is summarized in Table 1. Labelling was present in the luminal and glandular epithelia and glandular lumina of the uterine horns (Figs 1 \& 2). It was visible along the basolateral cell membranes and in small granules dispersed either throughout the cytoplasm or concentrated in the apical regions of the cells. The intensity of label in the uterine epithelia varied with the stage of the oestrous cycle or day of pregnancy and was brightest at oestrus and Day 1 of pregnancy (Fig. 2). The pattern of labelling in the uterine body was similar to that seen in the uterine horns. In the cervix and vagina, labelling of sc was demonstrated in the superficial layer of cells in the stratified epithelia at pro-oestrus and Days 4 and 5 of pregnancy (Fig. 3). Labelling was also detected in this layer of the vaginal epithelium on Day 4 of pregnancy in 2 rats with surgically isolated vaginae. Labelling of sc 

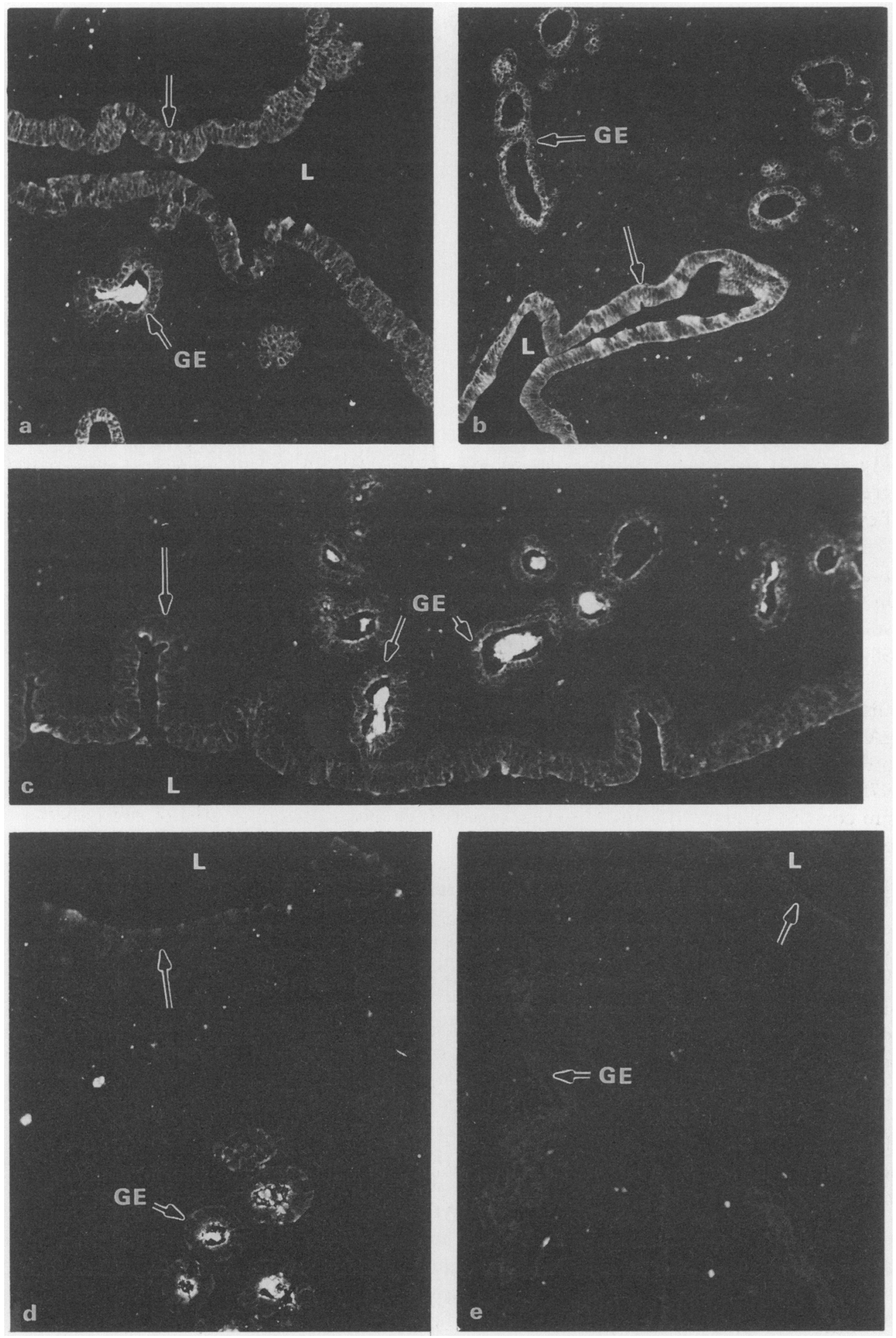
was detected in the oviducal epithelium on Day 1 of pregnancy, the only stage studied. No IgAcontaining lymphoid cells were detected in any part of the genital tract in cyclic or pregnant rats. This was the case for all tissues fixed in $4 \%$ paraformaldehyde, $2 \%$ acetic acid- $10 \%$ formalin in saline, or in frozen sections fixed in $100 \%$ methanol.

Labelling of sc was also observed in the glands associated with the urethra and in the superficial layer of cells in the stratified epithelium of the urethra. Plasma cells containing IgA were not observed in this tissue (Fig. 4).

\section{Discussion}

Secretory component was detected by immunofluorescence in uterine luminal and glandular epithelia and in the lumina of the uterine glands. The intensity of the label varied with the reproductive stage, reaching a maximum at pro-oestrus, oestrus, and Day 1 of pregnancy, and being weak or not detected by Day 7 of pregnancy. These observations are consistent with those of Sullivan \& Wira $(1981,1983)$, who reported that the amount of sc and $\operatorname{sIgA}$ in rat uterine fluids changed during the oestrous cycle, being highest at pro-oestrus, partly elevated at oestrus and absent at dioestrus. We did not detect any IgA-containing plasma cells in uterine horns at any stage examined. This is in agreement with Mitchell (1986), who reported an absence of IgA, IgG and IgM plasma cells in uteri of cyclic rats. Since we used three fixation procedures, including methanol-fixed cryostat sections, all of which preserved labelling of IgA in plasma cells in the duodenum, it seems unlikely that our failure to detect such plasma cells in the female reproductive tract was due to histological artefact. On the other hand, IgA-positive cells have been reported for intact rat uteri during the oestrous cycle and in ovariectomized animals treated with oestradiol (Wira et al., 1980; Wira \& Sullivan, 1982). The reasons for this discrepancy are not clear.

The presence of $s c$ in uterine epithelia accompanied by an absence of IgA-containing plasma cells suggests that there may be significant transport of serum IgA into uterine secretions. Serum IgA may also be a source of $\operatorname{sIgA}$ in uterine fluids in women, in whom sc is present in glandular epithelia but IgA-containing plasma cells are absent or sparse (Tourville et al., 1970; Rebello et al., 1975; Kelly \& Fox, 1979; Suzuki et al., 1984). The paucity of plasma cells in uteri of rats and women is in contrast with the accumulations of plasma cells demonstrated in uteri of other species. The reasons for and significance of this species variation are unknown.

The increased intensity of sc labelling in uterine horns at pro-oestrus, oestrus and Day 1 of pregnancy suggests that sc plays a more active role just before and at the time of mating. This is consistent with the suggestion that the secretory immune system in the mouse genital tract may be involved in returning the uterus to an aseptic state after mating (Parr, E. L. \& Parr, M. B., 1985). On Day 1 of pregnancy there were several species of bacteria in the uterine lumen which were probably introduced into the uterus from the vagina during mating. Many of the bacteria were coated with IgA or IgG, and naturally occurring antibodies with specificity for these bacteria have been demonstrated in mouse uterine and vaginal fluids (Parr, E. L. \& Parr, M. B., 1988).

The morphology of the vagina has generally been considered inappropriate for the existence of a secretory immune system because its epithelium is stratified and there is usually an absence of glands associated with the mucosa (Vaerman \& Ferin, 1974). In addition, secretory component was not detected in human vaginal epithelium by immunolabelling (Tourville et al., 1970). However, the present observation of sc in the rat vaginal epithelium at certain stages raises the possibility that

Fig. 2. Labelling of sc in luminal and glandular epithelia and glandular lumina in rat uteri at various stages. Note the reduction or absence of labelling in the epithelia on Days 5 and 7 of pregnancy. (a) Pro-oestrus, $\times 110$; (b) oestrus, $\times 90$; (c) Day 1 of pregnancy, $\times 110$; (d) Day 5 of pregnancy, $\times 180$; (e) Day 7 of pregnancy, $\times 170$. 

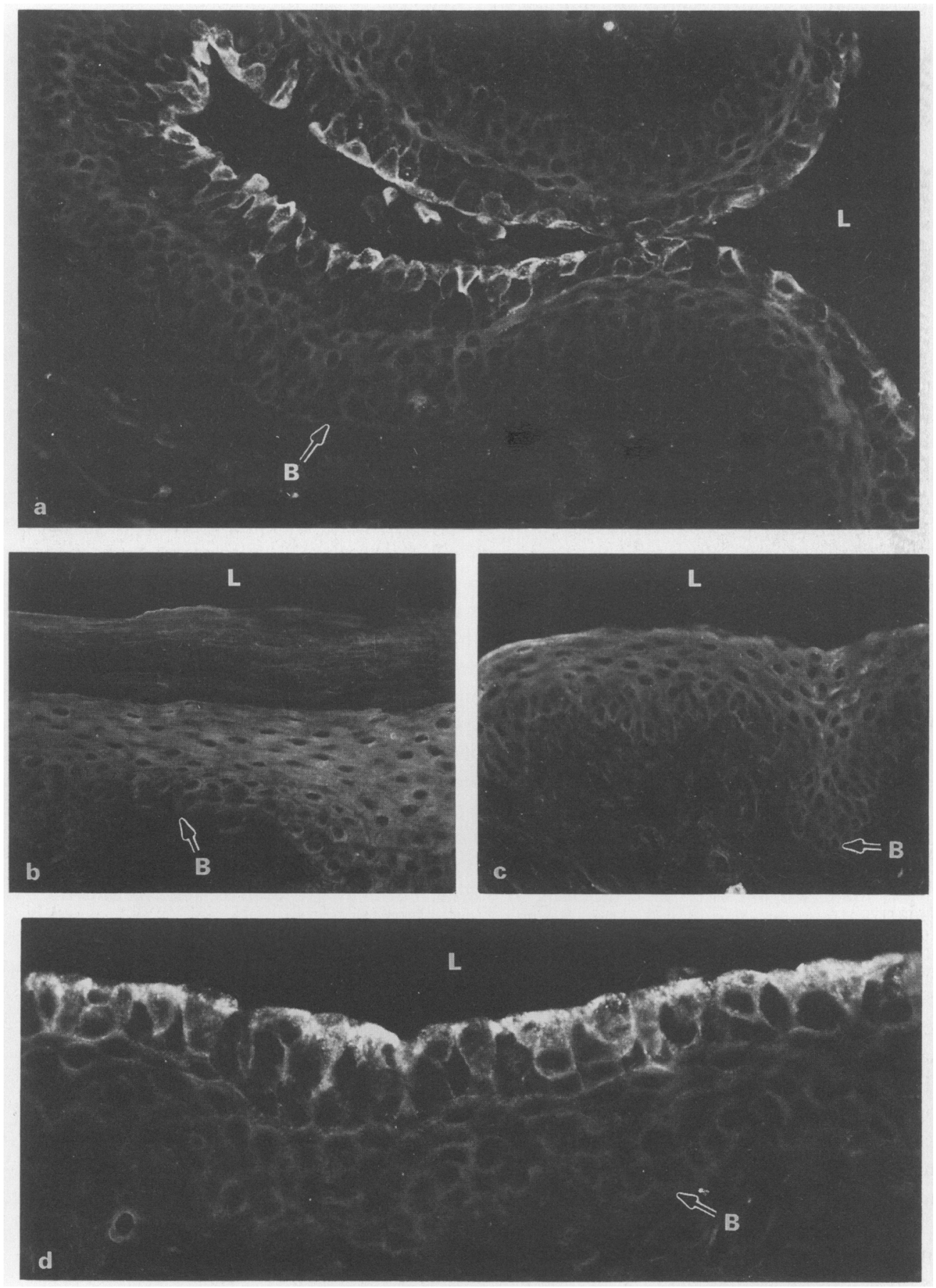

Fig. 3. Labelling of se in vaginal epithelia at the fornix region at various stages. Note the absence of labelling in the epithelia at oestrus and metoestrus. The latbelling of se at pro-oestrus and Day 4 was restricted to the layer of eells at the luminal surface of the stratified epithelium. B. basal lamina. (a) Pro-oestrus, $\times$ 200) (b) oestrus. $\times$ 180: (c) metocstrus. $\times 170$ : (d) Daly 4 of pregnancy, $\times 400$. 

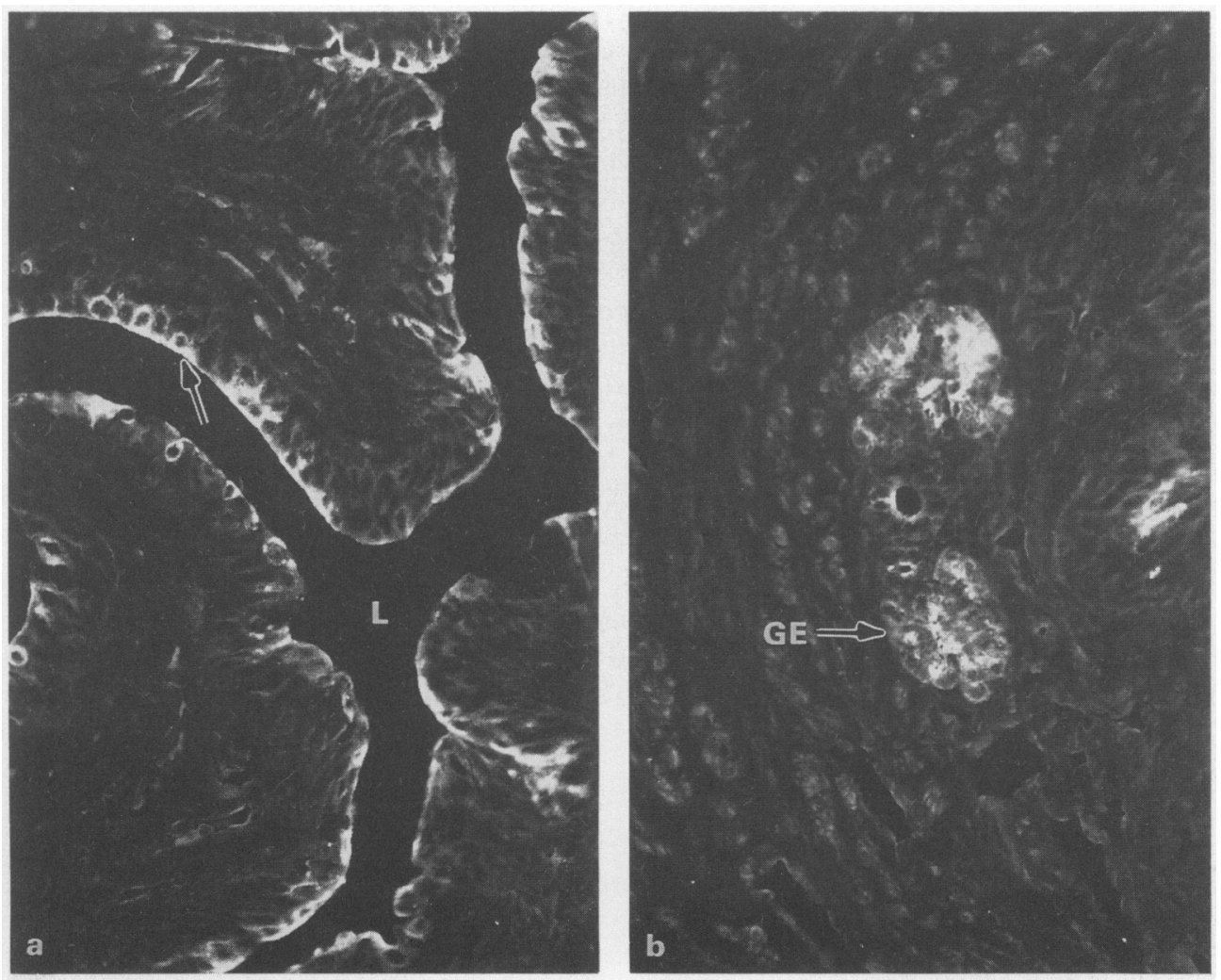

Fig. 4. Localization of sc in (a) the superficial layer of the urethral stratified epithelium (arrow) and (b) the urethral gland. L, urethral lumen; GE, glandular epithelium. (a) $\times 190$; (b) $\times 170$.

IgA may be transported across this layer. Polymeric IgA may percolate through the deeper layers of the vaginal epithelium by the intercellular route and then be taken up and transported intracellularly across the superficial layer of cells by an sc-mediated process. This view is consistent with studies of the permeability of vaginal epithelium which showed that ultrastructural tracers penetrated the intercellular spaces in the basal region but were excluded from these spaces at and superficial to the granular layer. The tracers did not penetrate significantly between cells at the free surface of the epithelium (monkey: King, 1983; guinea-pig: Winterhager \& Kuhnel, 1985). Analogous observations have been reported for structurally similar epithelia (epidermis: Elias \& Friend, 1975; oral epithelium: Squier \& Rooney, 1976). Roig de Vargas-Linares (1978) has proposed that immunoglobulins may cross the human vaginal epithelium by way of intercellular channels. However, the presence of tight junctions between some human vaginal epithelial cells (Burgos \& Roig de Vargas-Linares, 1978) raises some questions about this pathway, and no tracer studies have been reported.

The intensity of sc labelling in the epithelium of the uterine horns did not always correspond to that observed in the vaginal epithelium. The labelling in the uterine horns suggested that more sc was present at the time of insemination than at implantation. The more intense labelling of uterine sc just before and after ovulation coincides with a period of stromal oedema, suggesting that increased amounts of serum-derived IgA may also be present and that there may be increased transport of $\operatorname{IgA}$ into the uterine lumen at this time. It seems likely that the vagina also participates in secretory immunity at pro-oestrus, since sc was present in its epithelium at this time. However, at oestrus and Day 1 the vaginal epithelium is cornified and there is no detectable sc. The vaginal 
epithelium appears to serve mainly a barrier function at this time. During the implantation period, uterine horns showed reduced labelling which was mainly confined to the glandular lumina, while bright labelling of sc reappeared in the vaginal epithelium, suggesting that it resumes an active role at this time. These observations suggest that the regulation of $\mathrm{sc}$ in the uterine horns and vagina and the participation of these organs in secretory immunity may differ at various reproductive stages. Studies of the hormonal control of sc and $\operatorname{IgA}$ in cervico-vaginal secretions of the rat have also indicated that there are differential responses in the uterine horns and cervico-vaginal region (Wira \& Sullivan, 1985).

The presence of sc in the stratified epithelium of the urethra and in urethral glands in the female rat suggests that IgA may be transported into urine at these sites. In the male rat labelling of sc was absent in the urethral epithelium but was detected in the urethral glands (Parr, M. B. \& Parr, E. L., 1989). These observations suggest that IgA may be transported into the distal portion of the rat urinary tract, but the sites of $\operatorname{IgA}$ secretion may differ between the sexes. Secretory IgA has been reported in human urine from normal females (Bienenstock \& Tomasi, 1968), and studies of a possible role for mucosal immunity in urinary tract infections would be of interest.

We thank Dr Brian J. Underdown (McMaster University, Ontario, Canada) for the generous contribution of purified rat sc, sIgA, and anti-rat sc antibody; Shonah Hunter for excellent technical assistance; Shereen Baig and Mark Themig for help in the laboratory; and Jeanette Robinson for accurately typing the manuscript. This work was supported by NIH research grant HD 17337.

\section{References}

Bernard, O., Rachman, F. \& Bennett, D. (1981) Immunoglobulins in the mouse uterus before implantation. J. Reprod. Fert. 63, 237-240.

Bienenstock, J. \& Tomasi, T.B. (1968) Secretory $\gamma$ A in normal urine. J. clin. Invest. 47, 1162-1171.

Burgos, M.H. \& Roig de Vargas-Linares, C.E. (1978) Ultrastructure of the vaginal mucosa. In The Human Vagina, pp. 63-93. Eds E. S. E. Hafez \& T. N. Evans. Elsevier/North Holland Biomedical Press, Amsterdam.

Canning, M.B. \& Billington, W.D. (1983) Hormonal regulation of immunoglobulins and plasma cells in the mouse uterus. J. Endocr. 97, 419-424.

Curtain, C.C., Clark, B.L. \& Dufty, J.H. (1971) The origins of the immunoglobulins in mucus secretions of cattle. Clin. exp. Immunol. 8, 335-344.

Elias, P.M. \& Friend, D.S. (1975) The permeability barrier in mammalian epidermis. J. Cell Biol. 65, 180-191.

Fisher, M.M., Nagy, B., Bazin, H. \& Underdown, B.J. (1979) Biliary transport of IgA: Role of secretory component. Proc. natn Acad. Sci. U.S.A. 76, 2008-2012.

Hussein, A.M., Newby, T.J., Stokes, C.R. \& Bourne, F.J. (1983) Quantitation and origin of immunoglobulins $A, G$, and $M$ in the secretions and fluids of the reproductive tract of the sow. J. Reprod. Immunol. 5 , 17-26.

Kelly, J.K. \& Fox, H. (1979) The local immunological defence system of the human endometrium. $J$. Reprod. Immunol. 1, 39-45.

Kenney, R.M. \& Khaleel, S.A. (1975) Bacteriostatic activity of the mare uterus: a progress report on immunoglobulins. J. Reprod. Fert., Suppl. 23, 357-358.

King, B.F. (1983) The permeability of nonhuman primate vaginal epithelium: a freeze-fracture and tracer-perfusion study. J. Ultrastruct. Res. 83, 99-110.

Long, J.A. \& Evans, H.M. (1922) The oestrous cycle in the rat and its associated phenomena. Mem. Univ. Calif. 6, 1-148.

Mazurkiewicz, J.E. \& Nakane, P.K. (1972) Light and electron microscopic localization of antigens in tissues embedded in polyethylene glycol with a peroxidase-labeled antibody method. J. Histochem. Cytochem. 20, 969-974.

Mitchell, B.S. (1986) The localisation of immunoglobulins in the non-pregnant rat uterus. J. Anat. 146, 237.

Ogra, P.L. \& Ogra, S.S. (1973) Local antibody response to poliovaccine in the human female genital tract. $J$. Immunol. 110, 1307-1311.

Parr, E.L. \& Parr, M.B. (1985) Secretory immunoglobulin binding to bacteria in the mouse uterus after mating. J. Reprod. Immunol. 8, 71-82.

Parr, E.L. \& Parr, M.B. (1988) Anti-bacterial IgA and IgG in mouse uterine luminal fluids, vaginal washings, and serum. J. Reprod. Immunol. 13, 65-72.

Parr, M.B. \& Parr, E.L. (1985) Immunohistochemical localization of immunoglobulins $A, G$ and $M$ in the mouse female genital tract. J. Reprod. Fert. 74, 361-370.

Parr, M.B. \& Parr, E.L. (1989) Immunohistochemical localization of secretory component and immunoglobulin $A$ in the urogenital tract of the male rodent. $J$. Reprod. Fert. 85, 115-124. 
Rebello, R., Green, F.H.Y. \& Fox, H. (1975) A study of the secretory immune system of the female genital tract. Br. J. Obstet. Gynaecol. 82, 812-816.

Roig de Vargas-Linares, C.E. (1978) The vagina as a source of immunoglobulins. In The Human Vagina, pp. 193-212. Eds E. S. E. Hafez \& T. N. Evans. Elsevier/North Holland Biomedical Press, Amsterdam.

Solari, R. \& Kraehenbuhl, J.P. (1985) The biosynthesis of secretory component and its role in the transepithelial transport of IgA dimer. Immunol. Today 6, 17-20.

Squier, C.A. \& Rooney, L. (1976) The permeability of keratinized and nonkeratinized oral epithelium to lanthanum in vivo. J. Ultrastruct. Res. 54, 286-295.

Sullivan, D.A. \& Wira, C.R. (1981) Estradiol regulation of secretory component in the female reproductive tract. J. Steroid Biochem. 15, 439-444.

Sullivan, D.A. \& Wira, C.R. (1983) Variations in free secretory component levels in mucosal secretions of the rat. J. Immunol. 130, 1330-1335.

Suzuki, M., Ogawa, M., Tamada, T., Nagura, H. \& Watanabe, K. (1984) Immunohistochemical localization of secretory component and IgA in the human endometrium in relation to menstrual cycle. Acta histochem. cytochem. 17, 223-229.

Tourville, D.R., Ogra, S.S., Lippes, L. \& Tomasi, T.B., Jr (1970) The human female reproductive tract: Immunohistological localization of $\gamma \mathbf{A}, \gamma \mathrm{G}, \gamma \mathrm{M}$, secretory "piece", and lactoferrin. Am. J. Obstet. Gynec. 108, 1102-1108.

Vaerman, J.P. \& Ferin, J. (1974) Local immunological response in the vagina, cervix, and endometrium. Acta endocr., Copenh., Suppl. 194, 281-305.
Waldman, R.H., Cruz, J.M. \& Rowe, D.S. (1971) Immunoglobulin levels and antibody to Candida albicans in human cervicovaginal secretions. Clin. exp. Immunol. 9, 427-434.

Winterhager, E. \& Kuhnel, W. (1985) Diffusion barriers in the vaginal epithelium during the estrous cycle in guinea pigs. Cell Tissue Res. 241, 325-331.

Wira, C.R. \& Sandoe, C.P. (1977) Sex steroid hormone regulation of $\operatorname{IgA}$ and $\mathrm{IgG}$ in rat uterine secretions. Nature, Lond. 268, 534-536.

Wira, C.R. \& Sullivan D.A. (1982) Effect of estradiol and progesterone on the secretory immune system in the female genital tract. Adv. exp. Med. Biol. 138, 99-111.

Wira, C.R. \& Sullivan D.A. (1985) Estradiol and progesterone regulation of immunoglobulin $\mathrm{A}$ and $G$ and secretory component in cervico-vaginal secretions of the rat. Biol. Reprod. 32, 90-95.

Wira, C.R., Hyde, E., Sandoe, C.P., Sullivan, D. \& Spencer, S. (1980) Cellular aspects of the rat uterine IgA response to estradiol and progesterone. $J$. Steroid Biochem. 12, 451-459.

Wira, C.R., Sullivan, D. \& Sandoe, C.P. (1983) Epithelial cell involvement in the estradiol-stimulated accumulation of $\operatorname{IgA}$ in the rat uterus. J. Steroid Biochem. 19, 469474.

Wolosewick, J.J. \& De Mey, J. (1982) In situ demonstration of tubulin and actin-containing structures in glutaraldehyde-fixed, PEG-embedded tissue sections. Anat. Rec. 202, 207A.

Received 13 April 1988 